\title{
ROLE OF FNAC VERSUS HISTOPATHOLOGY IN DIAGNOSIS OF VARIOUS BODY LUMPS
}

\author{
K. Altaf Hussain Talpur, Abdul Aziz Laghari, Arshad Mahmood Malik \\ and Sangrasi Ahmed Khan
}

\begin{abstract}
OBJECTIVE: To determine the diagnostic accuracy of FNAC versus histopathology in various body lumps.

DESIGN: Quasi-experimental study.

SETTING: Surgical department of Liaquat University Hospital Jamshorol Hyderabad, SindhPakistan, from January 2003 to December 2005.

PATIENTS AND METHODS: One hundred and sixty five patients with lumps at various body sites were studied. Patients were evaluated by history, examination and investigations. Then they underwent for FNAC followed by open biopsy. Reports of FNAC and histopathology were compared and accuracy of FNAC assessed.

RESULTS: Out of 165 cases, $92(55.76 \%)$ had neck lumps (with thyroid and extra-thyroid swellings, 46-cases each), 35 (21.21\%) breast lumps, 10 (6.06\%) parotid swellings and 11 (6.66\%) cases had axillary lump as main sites for FNAC, along with various other parts of body. FNAC revealed benign neoplastic conditions in $13.94 \%$ of cases, malignancy in $18.18 \%$, tuberculous lymphadenopathy in $14.54 \%$, goitre in $18.79 \%$, and inflammatory lesions in $11.52 \%$ of cases as main lesions with false negative results of $18.78 \%$ and false positive result of $0.60 \%$, whereas histopathology revealed malignancy in $24.85 \%$, benign neoplastic lesions in $20.0 \%$, goitres in $19.39 \%$, tuberculous lymphadenopathy in $23.03 \%$ as main disease problems.

CONCLUSION: FNAC has high sensitivity and specificity in diagnosis of various body lumps. Findings of this study are almost comparable to histopathology however, FNAC shows high false negative results which may be due faulty sampling technique or lack of expertise.
\end{abstract}

KEY WORDS: Lumps, FNAC, Biopsy, Histopathology, Sensitivity, Specificity.

\section{INTRODUCTION}

Fine needle aspiration cytology (FNAC) involves taking of a few representative cells from lump using a 2021 gauge needle followed by microscopic evaluation. FNAC gives immediate results, optimises diagnostic accuracy and minimizes the technique's insufficiency rate. ${ }^{1}$ It is in use for more than half a century but has gained worldwide acceptance during the last two decades. FNAC is a simple, useful and reliable procedure requiring only few minutes to complete and diagnosis can be made on the same day with several advantages over excisional biopsy. ${ }^{2}$ It can be performed in cases of outpatient department (OPD), thus making considerable savings in the cost of hospitalization.,4 The technique has established role in histological diagnosis of breast lumps, cervical lumps, lymphadenopathy and thyroid nodules. It does not only help to distinguish between benign and malignant lesions but also suggests nature of disease process. Generally, it is unable to differentiate in-situ from invasive carcinoma.

\section{PATIENTS AND METHODS}

This study of 3 years duration from January 2003 to December 2005 was carried out in the Department of Surgery at Liaquat University Hospital Jamshoro/ Hyderabad, Sindh - Pakistan. One hundred and sixty five patients with lumps at different body sites were included in the study after obtaining informed consent from the subjects. They were evaluated by history, examination and investigations. Sampling strategy was convenient and of non-probability technique. FNAC was performed with $10 \mathrm{cc}$ disposable syringe using 21 gauge needle. Slides were prepared and evaluated by cytopathologist. After FNAC, all patients 
underwent for incisional or excisional biopsy depending upon type of lesion. Histopathology and FNAC reports were compared and analysed for accuracy of FNAC. Data were analysed by SPSS 10.0 and the sensitivity and specificity of FNAC were compared with histopathology reports. The results were evaluated by following formulae:

$$
\begin{aligned}
& \text { (i) Sensitivity }=\frac{T P}{T P+F N} \times 100(\mathrm{FN}=\text { False negative }) \\
& \text { (ii) Specificity }=\frac{\mathrm{TN}}{\mathrm{TN}+\mathrm{FP}} \times 100 \quad(\mathrm{TN}=\text { True negative }) \\
&(\mathrm{FP}=\text { False Positive })
\end{aligned}
$$

\section{INCLUSION CRITERIA}

Study included patients of various age, irrespective of their sex having lumps of surgical etiology at different parts of body.

\section{EXCLUSION CRITERIA}

Patients with inconclusive FNAC or histopathology results, unfit for surgical procedures and lumps inaccessible to FNAC procedure were excluded from the study.

\section{RESULTS}

Of 165 patients, 55 (33.33\%) were male and 110 (66.66\%) females with male to female ratio of $1: 2$. Majority of patients i.e. $94(56.97 \%)$ presented in $3^{\text {rd }}$ and $4^{\text {th }}$ decades of life followed by $2^{\text {nd }}$ and $5^{\text {th }}$ decades in which there were $50(30.3 \%)$ patients. Neck swellings comprising thyroidal masses (27.88\%), extrathyroidal masses (27.88\%) and breast lumps (21.21\%) were common lesions for study along with lumps at various other parts of body (Table I). FNAC revealed neoplastic conditions both benign (13.94\%) and malignant (18.18\%), goitres (18.79\%) and tuberculous lymphadenopathy (14.54\%) as commonest cytological findings (Table II) with $18.78 \%$ false negative and $0.60 \%$ false positive results (Table III) having overall sensitivity of $80.61 \%$. However, histopathology revealed benign neoplastic lesions in $20.0 \%$, malignant in $24.85 \%$, tuberculous lymphadenopathy in $23.03 \%$ and goitres in $19.39 \%$ of cases as compared to FNAC with no false results (Table II). The sensitivity of FNAC of individual regions is given in (Table IV), where as it is compared to histopathology in table $\mathbf{V}$.
TABLE I:

SITE OF FNAC AND OPEN SURGICAL PROCEDURES

\begin{tabular}{|l|c|c|}
\hline \multicolumn{1}{|c|}{ Site of Procedure } & $\begin{array}{c}\text { No. of } \\
\text { Patients }\end{array}$ & Percentage \\
\hline Thyroid & 46 & $27.88 \%$ \\
\hline $\begin{array}{l}\text { Neck swellings other than } \\
\text { thyroid }\end{array}$ & 46 & $27.88 \%$ \\
\hline Breast & 35 & $21.21 \%$ \\
\hline Axilla & 11 & $6.66 \%$ \\
\hline Parotid gland & 10 & $6.06 \%$ \\
\hline Testes & 5 & $3.03 \%$ \\
\hline Back of body & 3 & $1.81 \%$ \\
\hline Arm & 3 & $1.81 \%$ \\
\hline Thigh & 2 & $1.21 \%$ \\
\hline Face & 1 & $0.6 \%$ \\
\hline Sub-mandibular gland & 1 & $0.6 \%$ \\
\hline Abdomen & 1 & $0.6 \%$ \\
\hline Inguinal region & 1 & $0.6 \%$ \\
\hline
\end{tabular}

TABLE II:

FINDINGS OF FNAC AND HISTOPATHOLOGY $(n=165)$

\begin{tabular}{|l|c|c|c|c|}
\hline \multicolumn{1}{|c|}{$\begin{array}{c}\text { Type of } \\
\text { Lesion }\end{array}$} & \multicolumn{2}{c|}{ FNAC } & \multicolumn{2}{c|}{ Histopathology } \\
\hline & Number & $\%$ & Number & $\%$ \\
\hline $\begin{array}{l}\text { Benign neoplastic } \\
\text { lesion }\end{array}$ & 23 & 13.94 & 33 & 20.0 \\
\hline $\begin{array}{l}\text { Malignant lesions } \\
\text { including lym- } \\
\text { phoma }\end{array}$ & 30 & 18.18 & 41 & 24.85 \\
\hline $\begin{array}{l}\text { Benign non- } \\
\text { neoplastic condi- } \\
\text { tions }\end{array}$ & 32 & 19.39 & 5 & 3.03 \\
\hline $\begin{array}{l}\text { Inflammatory } \\
\text { lesions }\end{array}$ & 19 & 11.52 & 7 & 4.20 \\
\hline $\begin{array}{l}\text { Tuberculous lym- } \\
\text { phadenopathy }\end{array}$ & 24 & 14.54 & 38 & 23.03 \\
\hline Goitre & 31 & 18.79 & 32 & 19.39 \\
\hline $\begin{array}{l}\text { Tuberculosis of } \\
\text { breast }\end{array}$ & 1 & 0.60 & 1 & 0.60 \\
\hline Reactive changes & 3 & 1.81 & 3 & 1.81 \\
\hline $\begin{array}{l}\text { Metastatic carci- } \\
\text { noma }\end{array}$ & 2 & 1.21 & 5 & 3.03 \\
\hline
\end{tabular}


K. Altaf Hussain Talpur, Abdul Aziz Laghari, Arshad Mahmood Malik, et al.

TABLE III:

FALSE RESULTS OF FNAC $(n=165)$

\begin{tabular}{|l|l|c|c|}
\hline \multicolumn{1}{|c|}{ Finding } & \multicolumn{1}{c|}{ Site } & Number & $\%$ \\
\hline $\begin{array}{l}\text { False Negative } \\
(\mathrm{n}=31,18.78 \%)\end{array}$ & $\begin{array}{l}\text { Lymph nodes } \\
(\text { Neck + Axilla) }\end{array}$ & $\begin{array}{c}13+3=1 \\
6\end{array}$ & 9.70 \\
\cline { 2 - 4 } & Breast & 8 & 4.85 \\
\cline { 2 - 4 } & Parotid gland & 4 & 2.42 \\
\cline { 2 - 4 } & Thyroid gland & 2 & 1.21 \\
\cline { 2 - 4 } & Back & 1 & 0.6 \\
\hline False Positive & Lymph node & 1 & 0.6 \\
\hline Sensitivity & $\begin{array}{l}\text { Remaining } \\
\text { patients }\end{array}$ & 133 & 80.61 \\
\hline
\end{tabular}

thy ${ }^{11}$, soft tissue tumours ${ }^{12}$ and may also suggest the nature of benign and malignant disease. In this study, FNAC revealed benign neoplastic conditions in $13.94 \%$, malignant in $18.18 \%$ and metastatic in $1.21 \%$ of cases whereas findings of histopathology revealed $20.0 \%, 24.85 \%$ and $3.03 \%$ respectively giving rise to $18.78 \%$ false negative and $0.60 \%$ false positive results. The reported rate of false negative results by Leonard $\mathrm{N}$ and Melcher $\mathrm{DH}^{13}$ is less than $5 \%$. The high false negative results in this study may be due to errors in sampling technique, and lack of expertise. FNAC has good sensitivity (85.29\%) and very high specificity (100\%) in breast lumps ${ }^{8}$. It is considered as first-line of investigation in any breast lump either primary or metastatic lesion. ${ }^{7}$ The integrated use of FNAC and radiological imaging provides most accuracy and sensitivity for detection of malignancy in non-

TABLE IV:

SENSITIVITY AND SPECIFICITY OF FNAC AT COMMON SITES OF BODY

\begin{tabular}{|l|c|c|c|c|c|}
\hline \multicolumn{1}{|c|}{ Site of Lesion } & No. of patients & $\begin{array}{c}\text { Patients with } \\
\text { +ve disease }\end{array}$ & False results & Sensitivity & Specificity \\
\hline Head and neck region & 104 & 84 & $\begin{array}{c}19 \\
\text { FN }=18 \\
\text { FP }=1\end{array}$ & 82.35 & 94.73 \\
\hline Thyroid gland & 46 & 44 & 2 & $95.65 \%$ & $100.00 \%$ \\
\hline Lymph nodes (Neck+Axilla) & 56 & 39 & $\begin{array}{c}17 \text { FN=16 } \\
\text { FP=1 }\end{array}$ & $70.90 \%$ & $94.12 \%$ \\
\hline Breast & 35 & 27 & 8 & $77.14 \%$ & $100.00 \%$ \\
\hline Axilla & 11 & 8 & 3 & $72.73 \%$ & $100.00 \%$ \\
\hline Parotid gland & 10 & 6 & 4 & $60.00 \%$ & $100.00 \%$ \\
\hline Testes & 5 & 5 & 0 & $100 \%$ & $100.00 \%$ \\
\hline
\end{tabular}

\section{DISCUSSION}

FNAC can be used in any age group of patients, even in children for diagnosis of infectious or neoplastic lesions. ${ }^{4}$ This study included patients of all age groups with highest number of cases in $3^{\text {rd }}$ and $4^{\text {th }}$ decade (56.97\%) whereas paediatric age group patients (1-14 years) were only 7 (4.24\%). The mean age of patients was 33.67 years. FNAC has been found well recognized diagnostic procedure for head and neck masses $^{2,5,6}$, breast lumps $s^{7,8,9}$ and abdominal masse ${ }^{10}$ under ultrasound or CT guidance. In this study, main areas involved were head and neck region including lymph nodes, thyroid and parotid gland (63.03\%) cases and breast $(21.21 \%)$ followed by axilla $(6.66 \%)$ and testes (3.03\%). The procedure is also helpful in diagnosis of benign and malignant lesions arising from different parts of body like cases of lymphadenopa- palpable lumps. ${ }^{14}$ In breast lesions, this study revealed sensitivity of $77.14 \%$ and specificity of $100 \%$ with false negative results of $4.85 \%$ whereas Hussain ${ }^{9}$ has reported sensitivity of $90.90 \%$ and specificity of $100 \%$ with false negative results of $9.1 \%$ which are quite high as compared with this study. FNAC can also help in surgical management of carcinoma of breast by selecting patients for frozen section examination and can thus spare the patients form additional procedure of excision or incision biopsy under separate anaesthesia. ${ }^{15}$ It is also useful in diagnosis of granulomatous mammary disease even if AFB cannot be demonstrated. ${ }^{16}$ In our patients, only $1(0.60 \%)$ case was proved as a mammary tuberculosis. FNAC has well established role in diagnosis of head and neck masses ${ }^{2}$ and has got $80 \%$ accuracy. ${ }^{5}$ The study by Tilak $\mathrm{V}$ et al, has shown accuracy of $92.73 \%$, sensitivity of $90.91 \%$ and specificity of $93.18 \%{ }^{6}$ This 
TABLE V:

SENSITIVITY OF FNAC AS COMPARED TO HISTOPATHOLOGY IN COMMON BODY LUMPS $(\mathrm{n}=152)$

\begin{tabular}{|c|c|c|c|c|c|}
\hline \multirow[t]{2}{*}{ Type of Lesion } & \multirow[t]{2}{*}{ Histopathology number } & \multicolumn{4}{|c|}{ FNAC } \\
\hline & & Number & False -ve & + ve & Sensitivity \\
\hline $\begin{array}{l}\text { Thyroid gland }(n=46) \\
\text { Goitre } \\
\text { Adenoma } \\
\text { Papillary Carcinoma } \\
\text { Undifferentiated Ca. } \\
\text { Hashimotos thyroiditis }\end{array}$ & $\begin{array}{c}32 \\
8 \\
4 \\
1 \\
1\end{array}$ & $\begin{array}{c}31 \\
8 \\
3 \\
1 \\
1\end{array}$ & $\begin{array}{l}1 \\
- \\
1 \\
- \\
-\end{array}$ & $\begin{array}{l}- \\
- \\
- \\
- \\
-\end{array}$ & $\begin{array}{c}96.87 \\
100.00 \\
75.00 \\
100.00 \\
100.00\end{array}$ \\
\hline $\begin{array}{l}\text { Lymph nodes }(\mathrm{n}=56) \\
\text { Tuberculosis } \\
\text { Metastatic carcinoma } \\
\text { Lymphoma } \\
\text { Non specific inflammation } \\
\text { Reactive hyperplasia }\end{array}$ & $\begin{array}{l}38 \\
5 \\
7 \\
3 \\
3\end{array}$ & $\begin{array}{l}24 \\
3 \\
8 \\
1 \\
3\end{array}$ & $\begin{array}{l}14 \\
2 \\
- \\
- \\
-\end{array}$ & $\begin{array}{l}- \\
- \\
1 \\
- \\
-\end{array}$ & $\begin{array}{c}63.16 \\
60.00 \\
100.00 \\
100.00 \\
100.00\end{array}$ \\
\hline $\begin{array}{l}\text { Breast }(n=35) \\
\text { Benign lesions (Fibro adenoma, } \\
\text { Fibrocystic disease) }\end{array}$ & 14 & 10 & 4 & - & 71.43 \\
\hline $\begin{array}{l}\text { Duct cell carcinoma. } \\
\text { Mastitis } \\
\text { Tuberculosis }\end{array}$ & $\begin{array}{l}17 \\
3 \\
1\end{array}$ & $\begin{array}{c}13 \\
3 \\
1\end{array}$ & $\begin{array}{l}4 \\
- \\
-\end{array}$ & $\begin{array}{l}- \\
-\end{array}$ & $\begin{array}{c}76.47 \\
100.00 \\
100.00\end{array}$ \\
\hline $\begin{array}{l}\text { Parotid }(n=10) \\
\text { Pleomorphic adenoma } \\
\text { Carcinoma } \\
\text { Lymphoma } \\
\text { Schawnoma }\end{array}$ & $\begin{array}{l}6 \\
2 \\
1 \\
1\end{array}$ & $\begin{array}{l}5 \\
1 \\
- \\
-\end{array}$ & $\begin{array}{l}1 \\
1 \\
1 \\
1\end{array}$ & $\begin{array}{l}- \\
- \\
-\end{array}$ & $\begin{array}{l}83.33 \\
50.00 \\
- \\
-\end{array}$ \\
\hline $\begin{array}{l}\text { Testes }(n=5) \\
\text { Inflmmatory diease } \\
\text { Seminoma }\end{array}$ & $\begin{array}{l}2 \\
3\end{array}$ & $\begin{array}{l}2 \\
3\end{array}$ & - & - & $\begin{array}{l}100 \\
100\end{array}$ \\
\hline
\end{tabular}

study shows sensitivity of $82.3 \%$ (84 cases), specificity of $94.73 \%$ with false negative results of $10.90 \%$ (18 cases) and false positive results of $0.6 \%$, in head and neck lumps. The sensitivity and specificity of FNAC for thyroid swellings were $95.65 \%$ and $100 \%$, for lymph nodes $70.90 \%$ and $94.12 \%$ respectively, whereas these were not helpful for rare lesions like dermoid cyst, branchial cyst, lipoma and haemangioma which were seen on histopathology. However, Daoud $\mathrm{FS}^{17}$ has reported its role in diagnosis of uncommon lesions like branchial cyst. Sensitivity and accuracy for thyroid given by Chiu WY et al, are $96.7 \%$ and $98.4 \%$ respectively. ${ }^{18}$ These results are comparable to the findings of this study. FNAC under ultrasound guidance permits higher diagnostic accuracy in evaluation of thyroid nodules not only by lessening false negative reports but more important, by decreasing false positive results. ${ }^{19}$ Overall, accuracy of FNAC in solitary nodules is $94.3 \%^{20}$ and in this study, it was $80 \%$ which is low as compared to above study. FNAC is a rapid, simple and effective diagnostic method for extrapulmonary tuberculosis ${ }^{21}$ involving the neck. It achieves diagnosis in $83 \%$ of cases of peripheral tuberculous lymphadenopathy along with acid-fast bacilli (FAB) smear examination ${ }^{22}$. Here, it has revealed $42.85 .90 \%$ accuracy in diagnosis of peripheral lymphadenopathy form different parts of body as compared to histopathology (67.85\%). It is also proved that cytological examination is helpful in distinguishing between benign and malignant diseases of lymph nodes and especially primary or recurrent Hodgkin's lymphoma ${ }^{23}$ and metastatic carcinoma ${ }^{24}$ so it is utilized as diagnostic technique in screening of lymphadenopathies ${ }^{23}$. In this study, FNAC revealed primary lymphoma in $4.85 \%$, metastatic disease in $1.21 \%$ of cases, whereas lymphoma in $4.24 \%$ and metastatic carcinoma in $3.03 \%$ of cases was confirmed on histopathology with $0.6 \%$ (one case) false positive report. 
FNAC is also very useful for diagnosis of salivary gland lesions especially for neoplastic conditions with sensitivity, specificity and diagnostic accuracy of $94.6 \%, 75 \%$ and $91.1 \%$ respectively. ${ }^{25}$ This study shows overall sensitivity of $60 \%$ and specificity of $100 \%$ for parotid gland lesions with accuracy of 83.33\% for pleomorphric adenoma, but it has failed to diagnose lymphoma and rare tumours like Schawnoma as seen on histopathology. However, it is even diagnostic for rare conditions arising from salivary glands like mucosa-associated lymphoma ${ }^{26}$ and sarcoidosis of parotid gland ${ }^{27}$ FNAC is equally helpful in diagnosis of testicular swellings such as tuberculosis and malignancy. ${ }^{28}$ In this study, it has given $100 \%$ sensitivity and specificity for inflammatory and malignant lesions but has failed to give nature of disease as proved on histopathology.

Overall conclusive results of FNAC in this study revealed malignancy in $18.18 \%$, benign neoplastic lesions in $13.94 \%$, benign non-neoplastic conditions in $19.39 \%$, inflammatory lesions in $12.12 \%$ and reactive changes in $1.81 \%$ cases with false negative results of $18.78 \%$ and false positive result in $0.6 \%$ of cases. Histopathology revealed malignancy in $24.85 \%$, benign neoplastic lesions in $20.0 \%$, non-neoplastic in $3.03 \%$, inflammatory lesions in $4.85 \%$ and reactive changes in $1.81 \%$ of cases.

\section{CONCLUSION}

FNAC has high sensitivity and specificity in diagnosis of various body lumps and its results are almost comparable to histopathology however FNAC shows high false negative results which may be due to faulty sampling technique or lack of expertise.

\section{REFERENCES}

1. Layfield LJ, Bentz JS, Gopez EV. Immediate onsite interpretation of fine needle aspiration smears: a cost and compensation analysis. Cancer. 2001; 93(5): 319-22.

2. Zimmer L, Johnson J. Fine needle aspiration of neck masses. Available at URL:www.emedicine.com/ent/topic561.htm.2003. Accessed on November 22, 2006.

3. Frable WJ. Thin needle aspiration biopsy. Am J Clin Pathol. 1979; 65:168-80.

4. Silverman JF, Gurley AM, Holbrook CT, Joshi VV. Pediatric fine needle aspiration biopsy. Am J Clin Pathol. 1991; 95(5): 653-9.

5. Guyot JP, Obradovic D, Krayenbhul M, Zbaeren $\mathrm{P}$, Lehmann $\mathrm{W}$. Fine needle aspiration in the diagnosis of neck growths: is it necessary? Otolaryngol Head Neck Surg. 1990; 103 (5): 697-701.

6. Tilak V, Dhadad AV, Jain R. Fine needle aspiration cytology of head and neck masses. Indian J
Pathol Microbiol. 2002; 25 (1):23-9.

7. Shukla R, Pooja B, Radhika S, Nijhawan R, Rajwanshi A. Fine needle aspiration cytology of extra mammary neoplasms; matastatic to breast. Diagn Cyto Pathol. 2005; 32(4): 193-7.

8. Aziz M, Ahmed N, Zahid J, Faizullah. Comparison of FNAC and open biopsy in palpable breast lumps. J Coll Physicians Surg Pak. 2004; 14 (11):654-6.

9. Hussain MT. Comparison of fine-needle aspiration cytology with excision biopsy of breast lumps. J Coll Physicians Surg Pak. 2005; 15(4):211-4.

10. Asghar F, Riaz S. Comparison of diagnostic reliability of abdominal masses by ultrasound guided fine needle aspiration cytology (FNAC) with histology. Pak J Pathol. 2006; 17(3):97-100.

11. Alash NI, Abdul Majeed BA, Al-Hashmi AS. Lymphadenopathy: histopathologic study of 1145 biopsies. J Faculty Med Baghdad Uni. 1994; 36:171-9.

12. Bezabih M. Cytological diagnosis of soft-tissue tumours. Cytopathology 2001;12(3):177-83.

13. Leonard N, Melcher DH. To operate or not to operate? The value of fine-needle aspiration cytology in assessment of thyroid swellings. J Clin Pathol. 1997; 50(11):941-3.

14. Sampatanuk $P$, Boonjunwetwat $D$, Thanakit $V$, Pak-Art P. Integrated criteria of fine needle aspiration cytology and radiological imaging for verification of breast cancer in non-palpable lesions. J Med Assoc Thai. 2006; 89(2):236-41.

15. Tariq GR, Haleem A, Zaidi AH, Afzal M, Abbasi S. Role of FNA cytology in management of carcinoma breast. J Coll Physicians Surg Pak. 2005;15 (4):207-10.

16. Elsiddig KE, Khalid EA, Elhag IA, et al. Granulomatous mammary disease: ten years experience with fine-needle aspiration cytology. Int J Tuber Lung Dis. 2003; 7(4): 365-9.

17. Daoud FS. Branchial cyst: an often forgotten diagnosis. Asian J Surg. 2005;28(3):207-10.

18. Chiu WY, Chia NH, Wan Sk, Yuen $\mathrm{CH}$, Cheung MT. The investigation and management of thyroid nodules, a retrospective review of 183 cases. Ann Acad Med Singapore 1998; 27(2):196-9.

19. Solymosi T, Toth GI, Bodo M. Diagnostic accuracy of fine-needle aspiration cytology of the thyroid: impact of ultrasonography and ultrasonographically guided aspiration. Acta Cytol. 2001; 45 (5):669-74.

20. Siddiqui FG. Role of fine-needle aspiration cytology in the diagnosis of clinically solitary nodule. $\mathrm{J}$ Coll Physicians Surg Pak. 2000; 10(10):365-7.

21. Asayama I, Ishikawa T, Yamada T, Kitagawa W, Shimizu K. A case of tuberculous granuloma at 
the suprasternal notch that was difficult to differentiate from thyroid cancer. Med Sci Monitor. 2005; 10(8): 37-40.

22. Hussain M, Rizvi N. Clinical and morphological evaluation of tuberculous peripheral lymphadenopathy. J Coll Physicians Surg Pak. 2003;13 (12):694-6.

23. Jimenez-Heffernan JA, Vicandi B, Lopez-Ferrer $P$, Hardisson D, Vigner JM. Value of fine-needle aspiration cytology in initial diagnosis of Hodgkin's disease: analysis of 188 cases with an emphasis on diagnostic pitfalls. Acta Cytol. 2001; 45(3): 300-6.

24. Martelli G, Pilotti S, Lepera P,et al. Fine-needle aspiration cytology in superficial lymph nodes; an analysis of 266 cases Eur J Sur Oncol. 1989;15
(1): 13-6.

25. Das K, Petkar MA, Al-Mane NM, Sheikh ZA, Malik MK, Amin JT. Role of fine-needle aspiration cytology in the diagnosis of swellings in the salivary gland regions: a study of 712 cases. Med Princ Pract. 2004;13(2):95-106.

26. Erkan AN, Cagiei CA, Aka-Bolal F, Ozluoglu LN. A case of mucosa-associated lymphoid tissue lymphoma of parotid gland. Kulak Burun Bogaz Ihtis Derg. 2005; 14 (3-4): 87-91.

27. Sinha R, Gaur SN. Sarcoidosis presenting as acute bilateral parotid swelling. Asia Pac J Allergy Imunol. 2004; 22(2-3):171-4.

28. Kundu S, Sengupta A, Dey A, Thakur SB. Testicular tuberculosis mimicking testicular malignancy. J Indian Med Assoc. 2004; 102(5):270.

AUTHOR AFFILIATION:

Dr. K. Altaf Hussain Talpur (Corresponding Author) Assistant Professor of Surgery Ward-5, Surgical Unit-I Liaquat University of Medical \& Health Sciences (LUMHS) Jamshoro, Sindh-Pakistan.

\section{Dr. A. Aziz Laghari}

Associate Professor of Surgery

LUMHS, Jamshoro, Sindh-Pakistan.

Dr. Arshad Mahmood Malik

Assistant Professor of Surgery

LUMHS, Jamshoro, Sindh-Pakistan.

Dr. Ahmed Khan Sangrasi

Assistant Professor of Surgery

LUMHS, Jamshoro, Sindh-Pakistan. 